\title{
Listeria monocytogenes meningitis: an opportunistic infection
}

\author{
JOHN F. SIMPSON \\ From the Department of Neurology, University of Michigan Medical Center, Ann Arbor, Michigan, U.S.A,
}

SUMMARY Meningitis caused by L. monocytogenes is discussed from the standpoints of clinical presentation and course, underlying illness, and altered host resistance. The 'opportunistic' nature of the infection is emphasized, and case histories of patients with diseases which may specifically alter host resistance in such a fashion as to render the patient susceptible to this organism, or who are receiving drugs which may have the same result, are presented. The critical role of host macrophages, and the alteration of this role by Hodgkin's disease, leukaemia, and cytotoxic drug therapy are emphasized.

A micro-organism may be termed an 'opportunist' if it produces infections in certain specific settings of altered host resistance. Examples include Cryptococcus neoformans, Mucoraceae, and Listeria monocytogenes. Illnesses reducing host resistance and thereby predisposing to opportunistic infections include diabetes mellitus and malignancy, especially leukaemia and lymphoma. Treatment with either steroids or cytotoxic drugs, such as azathioprine, 6mercaptopurine, methotrexate, or nitrogen mustard, may also reduce host resistance with similar results.

L. monocytogenes is an organism which is particularly apt to produce clinical infection in these circumstances and is being increasingly recognized as such an 'opportunist'. Whereas meningitis and other infections caused by this organism were formerly regarded as largely confined to infants and newborns, increasing numbers of case reports attest to a growing recognition of the organism as a wide-spectrum pathogen, particularly in certain circumstances. The purpose of this paper is to demonstrate these circumstances by appropriate case reports, to discuss the problems posed by $L$. monocytogenes meningitis, and to present some possible pathogenic mechanisms for its occurrence in certain patients.

CASE 1

Female, aged 25. The diagnosis of Hodgkin's disease was established at the age of 17 . The disease followed a fluctuating but generally downhill course for the ensuing seven years, marked by episodes of weakness, low-grade fever, the appearance of adenopathy in the retroperitoneal and cervical regions, and the development of lesions in the lungs and bones. Several hospitalizations were required for irradiation, chemotherapy, and blood transfusions. At the time of the present admission, she complained of malaise, oedema, intermittent fever, and clouding of consciousness. She had not received chemotherapy in the several months beforehand. On examination her temperature was $38.3^{\circ} \mathrm{C}\left(101^{\circ} \mathrm{F}\right)$. She was seriously ill and emaciated. Her liver and spleen were enlarged and there was diffuse adenopathy. She did not exhibit focal neurological signs but she was obtunded. Her neck was supple and straight-leg-raising was normal. Skin tests to tuberculin, histoplasmin, coccidioidin, and blastomycin were negative. Blood cultures revealed $L$. monocytogenes. Lumbar puncture revealed slightly xanthochromic fluid under normal pressure. There were 32 white blood cells (WBC) per c.mm of which $52 \%$ were polymorphonuclear leucocytes, $46 \%$ were lymphocytes, and $2 \%$ were monocytes. The glucose was $13 \mathrm{mg} / 100 \mathrm{ml}$. with a concurrent blood glucose of $100 \mathrm{mg} / 100 \mathrm{ml}$. Intravenous penicillin, 20,000,000 units per day, and intravenous hydrocortisone were administered. Several grand mal seizures occurred in the subsequent two days. Nevertheless, striking improvement in mental state occurred in approximately three days, coincident with disappearance of fever. Her general condition continued to worsen, however, and she died several weeks later. The necropsy revealed widespread Hodgkin's disease but the central nervous system was entirely normal.

\section{CASE 2}

Male, aged 48. The diagnosis of polycystic kidney disease was established in 1952. Frank uraemia occurred in 1969 and he was repeatedly dialysed. In October of 1969 he underwent bilateral nephrectomy and received a cadaver 
renal transplant. At this time he began taking the following medications: prednisone, $90 \mathrm{mg}$ per day; azathioprine, $200 \mathrm{mg}$ per day, and nystatin, 200,000 units per day. Subsequently, prednisone was reduced to $45 \mathrm{mg}$ per day. These medications were continued until the time of his current admission four months later.

The admission was necessitated because of the abrupt onset of chills, fever, and malaise. On examination he appeared cushingoid and his temperature was $37 \cdot 8^{\circ} \mathrm{C}$ $\left(100^{\circ} \mathrm{F}\right)$ orally. His general physical and neurological examinations were otherwise normal.

His WBC was 47,000 per c.mm. with a normal differential count. Numerous blood cultures were obtained at admission and seven were positive for $L$. monocytogenes, type 4-B. Lumbar puncture revealed clear fluid with a pressure of $200 \mathrm{~mm}$. The protein was $76 \mathrm{mg} / 100 \mathrm{ml}$. but there were no other abnormalities. Intravenous penicillin and erythromycin were administered. On the fifth hospital day the patient had a grand mal seizure and was noted to have a stiff neck. Another lumbar puncture was performed and the pressure was $320 \mathrm{~mm}$. The fluid appeared turbid. The protein was $225 \mathrm{mg} / 100 \mathrm{ml}$. and the glucose was less than $20 \mathrm{mg} / 100 \mathrm{ml}$. with a concurrent blood glucose of $90 \mathrm{mg} / 100 \mathrm{ml}$. The white blood cell count was 270 per c.mm with $70 \%$ polymorphonuclear leucocytes and $30 \%$ mononuclear cells. Cultures of the cerebrospinal fluid also grew out L. monocytogenes, type 4-B. Antibiotics were continued and anticonvulsants were also administered. A right peripheral facial palsy appeared but he began to improve shortly thereafter and made an uneventful recovery.

\section{CASE 3}

Male, aged 57. This patient had been treated for three years for diabetes mellitus and for anaemia of undetermined aetiology. He suffered from intermittent severe weakness, mental 'dullness', lethargy, and episodic s tupor. He complained of intermittent epigastric pain and sore tongue. He stated that his hair had been grey since the age of 29 .

On examination he was lethargic and slow in responding, but oriented. He exhibited constant to-and-fro movements of his tongue. His gait was mildly unsteady. His neurological examination was otherwise normal. Microaneurysms were present in both fundi. His liver and spleen were enlarged.

Blood studies included haemoglobin of $6.4 \mathrm{~g} / 100 \mathrm{ml}$., haematocrit $22 \%$, white cell count 4,000 per c.mm with $71 \%$ polymorphonuclear leucocytes, $12 \%$ monocytes, and $13 \%$ lymphocytes. A reticulocyte count was $2.8 \%$ and a platelet count was 39,000 per c.mm. Bone marrow examination showed erythroid hyperplasia and reticulocytosis. Several stool specimens contained occult blood. Serum protein electrophoresis revealed $5.9 \mathrm{~g}$ total protein,

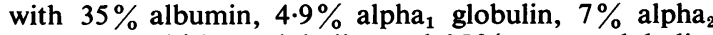
globulin, $18 \%$ beta globulin, and $35 \%$ gamma globulin. A gastric analysis revealed achlorhydria. A Schilling test without intrinsic factor revealed $1 \cdot 3 \%$ excretion while the value was $14 \%$ with intrinsic factor. The serum iron was $28 \mu \mathrm{g}$ per $100 \mathrm{ml}$. A BSP test revealed $41 \%$ retention. The results of alkaline phosphatase, bilirubin, and SGOT determinations were normal. Gastroscopy revealed an antral lesion appearing to be gastric carcinoma.

Because of evidence suggesting hypersplenism, hydro- $\stackrel{\text { C }}{\subseteq}$ cortisone, $200 \mathrm{mg}$ per day, was begun. Concurrently, low-ē grade fever and obtundation developed. Several blood $\bigcirc$ cultures were obtained and lumbar puncture was performed. The pressure was normal but there were $960 \stackrel{\circ}{\supset}$ cells/c.mm of which $90 \%$ were polymorphonuclear leucocytes; the glucose was $109 \mathrm{mg} / 100 \mathrm{ml}$. with a concurrent blood glucose of $230 \mathrm{mg} / 100 \mathrm{ml}$. The protein was $70 \mathrm{mg} / 100 \mathrm{ml}$. Cultures of cerebrospinal fluid yielded $\stackrel{5}{\rightarrow}$ L. monocytogenes. Subsequently, urine and blood음 cultures also yielded this organism.

Intravenous penicillin, 10,000,000 units per day, and $\overline{\bar{c}}$ erythromycin, $4 \mathrm{~g}$ per day, were administered. His $\vec{D}$ mental status became normal in two days and he felt $\varrho$ much better. Lumbar puncture repeated 12 days later was normal. However, his liver function studies continued $\vec{\circ}$ to be abnormal.

Repeat gastroscopy was normal. It was speculated that $\overrightarrow{\vec{\omega}}$ the lesion previously seen might represent a Listeria granuloma.

Two possible means of contact with $L$. monocytogenes were discovered. The patient owned two dogs, one of $\omega$ which died several months before the patient's illness of $\frac{}{\sigma}$ some type of central nervous system disease. A secong dog, still in the home, had a conjunctival discharge and apparent visual difficulties. This dog was sacrificed whit 0 the patient was in the hospital. Examination of the dog liver revealed many small abscesses which were positiz $\vec{\square}$ for $L$. monocytogenes when examined by immun fluorescence microscopy.

Secondly, the patient in the adjacent bed had had episode of $L$. monocytogenes meningitis approximate 12 months previously. He was clinically well at this tint however.

\section{CASE 4}

Male, aged 45. This patient had noted weight loss, persistent cough, and dysphagia for several months before his present admission. Six weeks before admission he $\frac{\mathrm{Q}}{\mathbb{Q}}$ noted enlargement of lymph nodes in the neck, increasing $\varrho$ fatigue, dyspnoea, and hoarseness. Two lymph node $\overrightarrow{\overline{0}}$ biopsies were obtained and were interpreted as lympho- $\frac{0}{3}$ sarcoma. Cyclophosphamide and prednisone were $\vec{F}$ administered, but symptoms increased and he developed persistent fever.

At the time of admission, he was critically ill. His temperature was $38.9^{\circ} \mathrm{C}\left(102^{\circ} \mathrm{F}\right)$. He complained of headache and double vision and was mildly confused. His neck was stiff. A mild left hemiparesis was noted. His liver and spleen were both moderately enlarged. Several grand $\hat{\partial}$ mal convulsions occurred shortly after admission.

The laboratory studies on admission revealed a haemoglobin of $8 \cdot 2 \mathrm{~g} / 100 \mathrm{ml}$, white cell count 20,700 per c.mm. 글 with $73 \%$ polymorphonuclear leucocytes, $21 \%$ lympho- $\frac{D}{O}$ cytes, $4 \%$ monocytes, and $2 \%$ eosinophils. Skin tests to tuberculin, histoplasmin, coccidioidin, and blastomycin $\mathrm{N}$ were negative.

Several blood cultures were obtained at the time of $\mathrm{N}$ admission and these all yielded $L$. monocytogenes. 
Lumbar puncture revealed a turbid fluid under normal pressure. Analysis revealed a protein of $1.2 \mathrm{~g} / 100 \mathrm{ml}$. The white blood cell count was 1,000 per c.mm, of which $95 \%$ were polymorphonuclear leucocytes.

Intravenous penicillin and tetracycline were administered. Improvement in mental status and meningeal symptoms occurred promptly thereafter. However, evidence of underlying illness - persisted, including congestive heart failure, diffuse lymphadenopathy, pleural effusions, and pneumonia.

\section{CASE 5}

Female, aged 68. Several months before the current admission a diagnosis of acute monocytic leukaemia (Schilling type) was established. One month before the present admission she had been hospitalized for chemotherapy including vincristine, 6-mercaptopurine, methotrexate, and prednisone. Clinical improvement had occurred, coincident with a decrease in lymphadenopathy, regression of spleen size, and absence of blast cells in peripheral blood.

Persistent fatigue and anorexia were the principal complaints at the time of the present admission. On physical examination she was noted to be alert and fully competent mentally. Several bruises were noted on the skin. No visceral organs were palpable nor were there any palpable lymph nodes. The initial haemoglobin was $6.5 \mathrm{~g} / 100 \mathrm{ml}$. and the white cell count 2,800 per $\mathrm{c} . \mathrm{mm}$ with a marked shift to the left. Bone marrow examination was interpreted as 'an acute blastic crisis'. Intermittent fever began shortly after admission, reaching $40^{\circ} \mathrm{C}\left(104^{\circ} \mathrm{F}\right)$. Progressive leucopenia occurred with the total white blood cell counts falling to 500 per c.mm. Intermittent episodes of difficulty in speaking, interpreted as aphasia, were then noted. Lumbar puncture revealed xanthochromic fluid under normal pressure. There were 53 white blood cells per c.mm, $44 \%$ of which were lymphocytes and $56 \%$ polymorphonuclear leucocytes. The protein was $320 \mathrm{mg} / 100 \mathrm{ml}$. and the glucose $93 \mathrm{mg} / 100 \mathrm{ml}$. Culture of the cerebrospinal fluid revealed $L$. monocytogenes, type I, and a blood culture drawn at approximately the same time yielded the same organism.

Intravenous penicillin was administered but the patient's condition worsened rapidly and she died approximately 48 hours after admission.

\section{CASE 6}

Male, aged 15. A diagnosis of acute stem-cell leukaemia was established 10 months before admission after an approximately six-month illness characterized by fatigue, headaches, anorexia, and episodes of chills and fever. Characteristic bone marrow and peripheral blood examinations were noted. The patient was begun on chemotherapy and was followed in the outpatient department. At varying times in the ensuing months he received prednisone, $80 \mathrm{mg}$ a day, 6-mercaptopurine, methotrexate, and vincristine. For several weeks before his admission he had noted pains in his legs, increasing weakness and fatigue, and persistent vague headaches. A week before admission he complained of a sore throat, perspired freely and had a shaking chill. These symptoms abated but fatigue persisted.
On the morning of admission he had a coughing spell and felt extremely short of breath. He became cold and clammy. He was noted to behave inappropriately and to be unable to express himself coherently. He was ataxic when he attempted to use his arms and hands and occasionally had random, jerking movements of the extremities. He complained of inability to see clearly and of double vision. On the day before admission he had a severe but short-lasting headache relieved by aspirin. He stated that his teeth felt loose and that he had an odd taste in his mouth.

On physical examination he was acutely ill with a temperature of $40.9^{\circ} \mathrm{C}\left(105.6^{\circ} \mathrm{F}\right)$. He was partially responsive. His arms occasionally jerked and twitched in a random fashion. His neck was supple and straight-legraising was normal. His respirations were periodic in nature. There was no evidence of increased intracranial pressure nor were there focal neurological signs.

His initial laboratory results included a total white blood cell count of 1,550 per c.mm with $50 \%$ polymorphonuclear leucocytes, $36 \%$ lymphocytes, 10 immature band forms, and 4 monocytes. Platelets were 136,000 per c.mm. Haemoglobin was $7 \cdot 3 \mathrm{~g} / 100 \mathrm{ml}$. Lumbar puncture revealed clear fluid under normal pressure. Analysis revealed normal glucose and protein levels. The white blood cell count was 300 per c.mm, all of which were polymorphonuclear leucocytes. Cerebrospinal fluid cultures and several blood cultures yielded $L$. monocytogenes, type I. Intravenous penicillin was administered in a dosage of $12,000,000$ units per 24 hours. His fever gradually lessened and disappeared on the sixth hospital day. His mental status slowly improved but he continued to eat very poorly and feel very tired.

Subsequent lumbar punctures revealed elevated protein values with normal glucose. Pleocytosis consisting largely of lymphocytes was consistently noted but cultures were negative.

Though the clinical evidence of neurological disease disappeared, the course of the underlying leukaemia was relentless and he died approximately three months later.

\section{DISCUSSION}

The neurological consultant asked to see a patient with a serious underlying disease, such as those reported herein, is confronted with the dilemma of whether the neurological symptoms are the result of nervous system involvement by the primary disease process, whether they are the result of medication, or whether they are produced by a secondary disease arising in a setting of lowered resistance. These complicated problems may be impossible to resolve. If, however, the physician is aware of certain specific settings for the occurrence of a secondary disease the evaluation can be more specifically directed and may be more fruitful. Such a disease is $L$. monocytogenes infection.

Listeriosis has now been widely reported from many parts of the world. Meningitis is most frequent but septicaemia, 'granulomatosis infantiseptica', an 
illness resembling infectious mononucleosis, abscess, subacute bacterial endocarditis and conjunctivitis have all been reported (Hoeprich, 1958; Seeliger, 1961; Murray, 1963; Gray, 1963a). The disease is well known in veterinary medicine but, in spite of widespread animal reservoirs, direct animal contact is uncommon (Gray, 1963b). Such a case has been reported here as case 3 . In most instances, human carriers are the most important reservoir. The organism, a small, Gram-positive rod, is commonly disregarded in the laboratory because of its resemblance to diphtheroids. The physician should be alert to laboratory reports mentioning 'contaminating diphtheroids'. Its distinctive growth and metabolism patterns have been well outlined elsewhere (Gray, 1962). Rapid identification and subtyping is possible using a fluorescent antibody technique (Eveland, 1963; Villella, Halling, and Biegeleisen, 1963) (Figure).

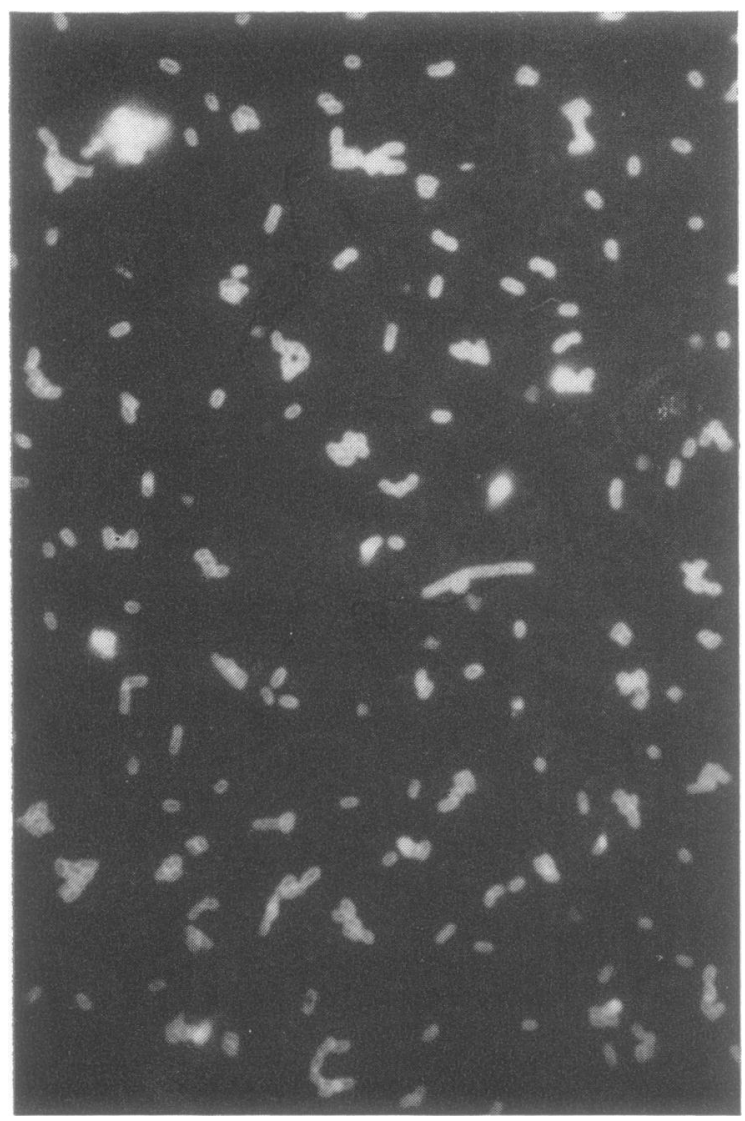

FIGURE. Smear of culture of cerebrospinal fluid from case 3, stained with anti-Listeria globulin conjugated with fluorescein isothiocyanate.
Meningitis caused by L. monocytogenes is an $\stackrel{\mathbb{D}}{=}$ exceedingly deceptive infection. Contrary to numerous statements in standard textbooks of medicine $\underset{0}{\stackrel{C}{a}}$ and neurology, the clinical picture is not typical and is not strictly comparable with meningococcal or streptococcal meningitis.

Though not surprising in the neonatal period, the most notable signs of meningitis, stiff neck, and. positive Kernig or straight-leg-raising signs, are $\vec{F}$ commonly absent in adults as well. Of 10 recent $\stackrel{\rho}{\stackrel{9}{+}}$ patients at the University of Michigan Medical Center, in only three did these signs develop in a $\frac{\bar{\sigma}}{\bar{N}}$ definite form.

Insidious and fluctuating signs of mental dys- $\stackrel{\mathbb{Q}}{\complement}$

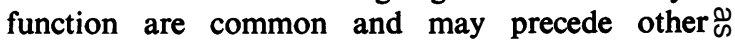
evidence of the infection by a week or more. Episodic $\vec{\circ}$ attacks of stupor or semi-stupor, during which the patient is aroused with difficulty, may alternate with $\vec{\omega}$ periods of clear sensorium. Persistent but rather mild $\stackrel{\Omega}{\text { ? }}$ lethargy and slowness of response may suggest only fatigue, depression, or the effects of sedative drugs. Bizarre delusions, illusions or hallucinations may be + reported. On the other hand, some patients have no changes whatever in mental status.

Convulsions occurred early in the course in seve of our patients and other focal neurological sigos such as peripheral facial nerve palsy, extraocular $\vec{\square}$ muscle palsy, and hemiparesis have occurred, though usually later. Abnormal movements, including air $-\frac{\mathbb{Q}}{3}$ less random arm movements and myoclonic jer may appear. In one patient the most promine initial finding was violent to-and-fro tongue move- $\overrightarrow{0}$ ments which persisted for several days (case 3).

Examination of cerebrospinal fluid yields results qualitatively similar to those in other forms of bacterial meningitis (Table 1). The pressure in five of the six cases reported herein was normal. Xanthochromia was observed in two and turbidity in two others. White cell counts do not reach the levels frequently encountered in other forms of bacterial $\overrightarrow{\overrightarrow{0}}$ meningitis; the highest total count in this group was 1,000 per c.mm. Differential counts vary, but a significant percentage of lymphocytes is usually found, even before therapy. In only two cases was the glucose level reduced significantly; many othero cases have been reported with normal cerebrospinalo fluid glucose. Therefore, this parameter, usually dependable in bacterial meningitis, should not be counted upon. Cultures of cerebrospinal fluid were $₹$ positive in all of the present cases and concurrent or윽 earlier blood cultures were positive in five of six.

The organism was sensitive to numerous anti-을 biotics in the cases surveyed by the author. Resistance was encountered only to lincomycin, cloxacillin, and \% oxacillin. Penicillin is accepted as the drug of choice ${ }_{0}^{N}$ but erythromycin is almost equally satisfactory. 
TABLE 1

CEREBROSPINAL FLUID EXAMINATION

\begin{tabular}{|c|c|c|c|c|c|c|c|c|}
\hline \multirow[t]{2}{*}{$\begin{array}{l}\text { Case } \\
\text { no. }\end{array}$} & \multirow[t]{2}{*}{$\begin{array}{l}\text { Opening } \\
\text { pressure }\end{array}$} & \multirow[t]{2}{*}{ Appearance } & \multicolumn{2}{|c|}{$\begin{array}{l}\text { Cell count: } \\
\text { total/c.mm }\end{array}$} & \multirow[t]{2}{*}{$\underset{(\mathrm{mg} / 100 \mathrm{ml} .)}{\text { Protein }}$} & \multirow{2}{*}{$\begin{array}{c}\text { Glucose: } \\
\text { CSF/blood } \\
\text { (mg/lo0 ml.) }\end{array}$} & \multirow[t]{2}{*}{$\begin{array}{l}\text { CSF } \\
\text { culture }\end{array}$} & \multirow[t]{2}{*}{$\begin{array}{l}\text { Blood } \\
\text { culture }\end{array}$} \\
\hline & & & $\%$ Poly & $\%$ Mono & & & & \\
\hline 1 & Normal & Xanthochromic & \multicolumn{2}{|c|}{32} & 120 & $13 / 100$ & + & + \\
\hline 2 & $320 \mathrm{~mm}$ & Turbid & \multicolumn{2}{|c|}{270} & 225 & $20 / 90$ & + & + \\
\hline 3 & Normal & Norma & \multicolumn{2}{|c|}{960} & 70 & $109 / 230$ & + & + \\
\hline \multirow[t]{2}{*}{4} & Normal & Turbid & \multicolumn{2}{|c|}{1,000} & 1,200 & Not. det. & + & - \\
\hline & Normal & Xanthochromic & \multicolumn{2}{|c|}{53} & 320 & $93 / 140$ & + & + \\
\hline 5 & Normal & Normal & 56 & $00 \quad 44$ & 70 & $61 / 97$ & + & + \\
\hline 6 & & & 100 & 0 & & & & \\
\hline
\end{tabular}

L. monocytogenes subtypes are apparently equally vulnerable to penicillin. The high susceptibility of the organism to antibiotic therapy coupled with the virulence of the untreated infection doubly emphasizes the importance of a high index of suspicion in this disease.

Analyses of large series of cases of listeriosis have revealed a significant association with certain serious illnesses (Gray, 1963a; Gray, 1963c). It is this striking association which is the focus of this paper. While it is not unexpected that secondary bacterial infections might occur in any person with a serious illness, the uncommonly high occurrence of $L$. monocytogenes infections in patients with Hodgkin's disease, leukaemia, lymphomas, and Laennec's cirrhosis, and the equally striking occurrence of infections by organisms with certain features in common with $L$. monocytogenes, such as $M$. tuberculosis, pathogenic fungi, Brucella, and Salmonella, are out of proportion to that expected and, therefore, may be particularly significant. In the discussion that follows, an attempt will be made to elucidate these common pathogenetic features and to emphasize the likelihood of infection under these circumstances.

Consideration of possible mechanisms whereby $L$. monocytogenes infections appear more frequently in association with certain illnesses or in association with the administration of certain drugs leads one to a consideration of the nature of the organism. $L$. monocytogenes is a facultative intracellular parasite; thus, it has the property of resistance to bactericidal processes within normal phagocytes and has the ability, at least in virulent strains, to multiply within phagocytes and destroy them. In addition to $L$. monocytogenes, many pathogenic fungi, $M$. tuberculosis, Salmonella, and Brucella organisms are all in this category (Suter and Ramseier, 1964). Since patients with leukaemia and lymphoma are unusually susceptible to infection with these organisms, an examination of common features in this group of organisms may be significant.

Animal infections with this group of organisms are characterized by a resistance against reinfection (Julianelle, 1941; Mackaness, 1962; Armstrong and Sword, 1964; Mackaness, 1964; Jenkin, Rowley, and Auzino, 1964; Rowley, Turner, and Jenkin, 1964). However, transfer of this resistance either to normal animals in vivo or into other macrophages in vitro via the serum has been unsuccessful (Miki and Mackaness, 1964; Mackaness, 1967). This evidence, coupled with the generally normal levels of antibody globulins in patients with Hodgkin's disease and lymphomas (Table 2) suggests that circulating antibody is a minor feature of resistance to these organisms (Hoffman and Rottino, 1950; Larson and Tomlinson, 1953; Arends, Coonrad, and Rundles, 1954; Schier, Roth, Ostroff, and Schrift, 1956; Aisenberg and Leskowitz, 1963; Aisenberg, 1964; Sword, 1966).

However, an enhanced capacity of macrophages to ingest and inhibit the multiplication of virulent Listeria has been demonstrated many times in animal infections (Mackaness, 1962; Armstrong and Sword, 1966; Goihman-Yahr, Raffel, and Ferraresi, 1969). The rapid production of an increased population of resistant macrophages also occurs, similar to that observed in infections with other facultative intra- 
TABLE 2

FACTORS RELEVANT TO HOST RESISTANCE

\begin{tabular}{|c|c|c|c|c|c|c|c|}
\hline \multirow{2}{*}{$\begin{array}{l}\text { Case } \\
\text { no. }\end{array}$} & \multirow[t]{2}{*}{ Underlying diseases } & \multicolumn{2}{|c|}{ Peripheral blood } & \multirow{2}{*}{$\underset{\text { globulin* }}{\text { Gamma }}$} & \multirow[t]{2}{*}{ Skin tests $\dagger$} & \multicolumn{2}{|c|}{ Treatment } \\
\hline & & $\begin{array}{l}\text { Poly } \\
(\%)\end{array}$ & $\underset{(\%)}{\text { Lymph }}$ & & & Steroids & Cytotoxic drugs \\
\hline $\begin{array}{l}1 \\
2\end{array}$ & $\begin{array}{l}\text { Hodgkin's disease } \\
\text { Polycystic kidney disease- } \\
\text { cadaver transplant }\end{array}$ & $\begin{array}{l}95 \\
65\end{array}$ & $\begin{array}{r}8 \\
30\end{array}$ & $\begin{array}{l}0.61 \mathrm{~g}(13.8 \%) \\
\text { 'Normal' }\end{array}$ & Cutaneous anergy & $\begin{array}{c}\text { No } \\
\text { Prednisone }\end{array}$ & $\begin{array}{c}\text { No } \\
\text { Azathioprine }\end{array}$ \\
\hline 3 & $\begin{array}{l}\text { Cirrhosis; diabetes; } \\
\text { ?pernicious anaemia }\end{array}$ & 71 & 13 & $2.0 \mathrm{~g}(35 \%)$ & & No & No \\
\hline $\begin{array}{l}4 \\
5\end{array}$ & $\begin{array}{l}\text { Lymphosarcoma } \\
\text { Acute leukaemia, monocytic }\end{array}$ & $\begin{array}{l}66 \\
\text { Sever }\end{array}$ & $\begin{array}{c}34 \\
\text { copenia }\end{array}$ & $(62 \%)$ & Cutaneous anergy & $\begin{array}{l}\text { Prednisone } \\
\text { Prednisone }\end{array}$ & $\begin{array}{l}\text { Cyclophosphamide } \\
\text { Vincristine } \\
\text { 6-mercaptopurine } \\
\text { methotrexate }\end{array}$ \\
\hline 6 & Acute leukaemia, stem-cell & 84 & 15 & & & Prednisone & $\begin{array}{l}\text { Vincristine } \\
\text { 6-mercaptopurine } \\
\text { methotrexate }\end{array}$ \\
\hline
\end{tabular}

* Normal 8.4-22\%. †Tuberculin, histoplasmin, coccidioidin, blastomycin (also negative complement fixation tests).

cellular parasites. This increased resistance, however, may be non-specific, since infection with one of this group may produce resistance to others in the same group (Goihman-Yahr et al., 1969).

This evidence suggests that a defect in cellular resistance, particularly involving macrophages, is likely in patients with Hodgkin's disease or lymphosarcomas (Simpson, Leddy, and Hare, 1967). Little or no information is available in the literature regarding studies of macrophage functions in patients with these illnesses, however.

Depression of delayed cutaneous hypersensitivity and of homograft reactions are encountered in $=!:$ gh proportion of patients with Hodgkin's disease as well as lymphosarcoma. Severe lymphopenia also occurs frequently in these patients, though it is not invariable (Aisenberg, 1964). Cutaneous anergy was demonstrated in cases 1 and 4. Steroid and antineoplastic drug therapy, of course, alters the interpretation of skin testing, as in case 4.

The role of delayed hypersensitivity reactions in clinical disease, however, is unresolved, in spite of the relationship to lymphopenia mentioned above, and the role of lymphocytes in resistance to this group of organisms is uncertain (Aisenberg, 1965; Gowans and McGregor, 1965; Mackaness, 1967).

The role of steroid drugs is a question of great importance in view of their known ability to suppress host resistance. In animal infections with $L$. monocytogenes, pretreatment with steroid drugs markedly enhances the likelihood of clinical infection (Nordland, 1960; Miller and Hedberg, 1965). Steroid dosage in experiments of this type is generally much higher than that used in human disease but this association has been reported several times and is undoubtedly an important factor. The effect may be related to the inhibition of delayed hypersensitivity reactions, by activating pre-existing infection or by interference with the function of polymorpho-o nuclear phagocytes or the mobilization of resistant ${ }_{\oplus}$ macrophages.

The use of cytotoxic drugs in certain diseases (cases 2, 5, and 6) may well be related to the develo ment of infection with L. monocytogenes. Discussions in the literature regarding the effect of drugs such $\mathbb{S}_{S}$ nitrogen mustard and 6-mercaptopurine have usua dy centred about the possibility of suppression of ${ }_{\mathscr{Q}}^{\infty}$ antibody formation (Levin, Landy, and Frei, 1964. However, as discussed above, suppression ef circulating antibody may be related only in a minor $\vec{\theta}$ way to increased susceptibility to Listeria infections. It is, of course, extremely important in infection with. organisms such as pneumococcus, which is an obligatory extracellular parasite. Resistance to these organisms relies upon neutralization of a phago-o cytosis-resistant capsule by means of opsonization with specific antibody. Conditions such as agamma- $\stackrel{\mathbb{Q}}{\complement}$ globulinaemia are therefore characterized by marked $\overrightarrow{\overrightarrow{0}}$ susceptibility to infections of this type.

However, other facts about this group of drugs $\vec{P}$ might well be considered in the present discussion. An? acute cytotoxic effect on macrophage population, as can occur with nitrogen mustard, or the inhibition of mononuclear cell activity at sites of inflammation:may be important (Page, Condie, and Good, 1964) Activation of latent infection, which is a feature of Listeria infections in general, is another possibility.

REFERENCES

Aisenberg, A. C. (1964). Immunologic aspects of Hodgkin's $N$ disease. Medicine (Balt.), 43, 189-193.

Aisenberg, A. C. (1965). Lymphocytopenia in Hodgkin's $N$ disease. Blood, 25, 1037-1042. 
Aisenberg, A. C., and Leskowitz, S. (1963). Antibody formation in Hodgkin's disease. New Engl. J. Med., 268, 1269-1272.

Arends, T., Coonrad, E. V., and Rundles, R. W. (1954). Serum proteins in Hodgkin's disease and malignant lymphoma. Amer. J. Med., 16, 833-841.

Armstrong, A. S., and Sword, C. P. (1964). Cellular resistance in listeriosis. J. infect. Dis., 114, 258-264.

Eveland, W. C. (1963). Demonstration of Listeria monocytogenes in direct examination of spinal fluid by fluorescentantibody technique. J. Bact., 85, 1448-1450.

Goihman-Yahr, M., Raffel, S., and Ferraresi, R. W. (1969). Delayed hypersensitivity in relation to suppression of growth of Listeria monocytogenes by guinea pig macrophages. J. Bact., 100, 635-640.

Gowans, J., and McGregor, D. (1965). The immunological activities of lymphocytes. Progr. Allergy, 9, 1-78.

Gray, M. L. (1962). Listeria monocytogenes and listeric infection in the diagnostic laboratory. Ann. N.Y. Acad. Sci., 98, 686-699.

Gray, M. L. (1963a). Listeric infection in man in the United States. In Second Symposium on Listeric Infection, pp. 290304. Edited by M. L. Gray. Montana State College: Bozeman, Montana.

Gray, M. L. (1963b). Epidemiological aspects of listeriosis. Amer. J. publ. Hth, 53, 554-563.

Gray, M. L. (1963c). Personal communication.

Hoeprich, P. D. (1958). Infection due to Listeria monocytogenes. Medicine (Balt.), 37, 143-160.

Hoffmann, G. T., and Rottino, A. (1950). Studies of immunologic reactions of patients with Hodgkin's disease. Antibody reaction to typhoid immunization. Arch. int. Med., 86, 872-876.

Jenkin, C. R., Rowley, D., and Auzins, I. (1964). The basis for immunity to mouse typhoid. I. The carrier state. Aust. J. exp. biol. med. Sci., 42, 215-228.

Julianelle, L. A. (1941). Biological and immunological studies of Listerella. J. Bact., 42, 367-383.

Larson, D. L., and Tomlinson, L. J. (1953). Quantitative antibody studies in man. III. Antibody response in leukemia and other malignant lymphomata. J. clin. Invest., 32, 317-321.

Levin, R. H., Landy, M., and Frei, E. III (1964). The effect of 6-mercaptopurine on immune response in man. New Engl. J. Med., 271, 16-22.
Mackaness, G. B. (1962). Cellular resistance to infection. $J$. exp. Med., 116, 381-406.

Mackaness, G. B. (1964). The immunological basis of acquired cellular resistance. J. exp. Med., 120, 105-120.

Mackaness, G. B. (1967). The relationship of delayed hypersensitivity to acquired cellular resistance. Brit. med. Bull., 23, 52-54.

Miki, K., and Mackaness, G. B. (1964). The passive transfer of acquired resistance to Listeria monocytogenes. J. exp. Med., 120, 93-103.

Miller, J. K., and Hedberg, M. (1965). Effects of cortisone on susceptibility of mice to Listeria monocytogenes. Amer. J. clin. Path., 43, 248-250.

Murray, E. G. D. (1963). Man. In Second Symposium on Listeric Infection, pp. 255-306. Edited by M. L. Gray. Montana State College: Bozeman, Montana.

Nordland, O. S. (1960). Host-parasite relations in initiation of infection. II. Hyperglycemia and stress in experimental infection with L. monocytogenes. Canad. J. comp. Med., 24, 57-74.

Page, A. R., Condie, R. M., and Good, R. A. (1964). Suppression of plasma cell hepatitis with 6-mercaptopurine. Amer. J. Med., 36, 200-213.

Rowley, D., Turner, K. J., and Jenkin, C. R. (1964). The basis for immunity to mouse typhoid. 3. Cell-bound antibody. Aust. J. exp. Biol. med. Sci., 42, 237-248.

Schier, W. W., Roth, A., Ostroff, G., and Schrift, M. H. (1956). Hodgkin's disease and immunity. Amer. J. Med., 20, 94-99.

Seeliger, H. P. R. (1961). Listeriosis. Hafner: New York.

Simpson, J. F., Leddy, J. P., and Hare, J. D. (1967). Listeriosis complicating lymphoma. Report of four cases and interpretive review of pathogenetic factors. Amer. J. Med., 43, 39-49.

Suter, E., and Ramseier, H. (1964). Cellular reactions in infection. Advanc. Immunol., 4, 117-173.

Sword, C. P. (1966). Serum protein alterations induced by. Listeria monocytogenes infections. J. Immunol., 96, 790-796.

Villella, R. L., Halling, L. W., and Biegeleisen, J. Z., Jr. (1963). A case of listeriosis of the newborn with fluorescent antibody histologic studies. Amer. J. clin. Path., 40, 151-156. 